\section{'MP-29', a Clonal Interspecific Hybrid Rootstock for Peach}

Thomas G. Beckman ${ }^{1,4}$

U.S. Department of Agriculture, Agricultural Research Service, Southeastern

Fruit and Tree Nut Research Laboratory, 21 Dunbar Road, Byron, GA 31088

Jose X. Chaparro² and Wayne B. Sherman ${ }^{3}$

University of Florida, Department of Horticultural Sciences, 1143 Fifield Hall, Hull Road, Gainesville, FL 32611

Additional index words. Prunus persica, P. umbellata, Armillaria, peach tree short life, PTSL, root-knot nematode
'MP-29' rootstock has been jointly released for grower trial by the U.S. Department of Agriculture, Agricultural Research Service (Byron, GA) and the Florida Agricultural Experiment Station. 'MP-29' is suggested for trial as a rootstock for peach (Prunus persica L. Batsch) varieties on Armillaria root rot (ARR) [Armillaria tabescens (Scop.:Fr.) Dennis et al.] infested sites where peach seedling type rootstocks often fail to provide satisfactory tree longevity. Peach varieties budded onto 'MP-29' rootstock displayed significantly better resistance to ARR than did trees on 'Guardian' or 'Sharpe' rootstocks. Trees on 'MP-29' displayed resistance to peach tree short life (PTSL) comparable to that of trees budded onto 'Guardian' peach seedling rootstock. 'MP$29^{\prime}$ also provides a marked reduction in tree vigor compared with peach seedling type rootstocks and may prove useful as a semidwarf rootstock where a less vigorous tree is preferred.

\section{Origin}

'MP-29' is an interspecific hybrid developed by the U.S. Department of Agriculture, Agricultural Research Service (USDA-ARS) at Byron, GA, from a cross made in 1994 between 'Edible Sloe', an apparent natural plum hybrid thought to include Prunus umbellata Elliot, and an advanced red-leafed peach rootstock selection from the Byron program, SL0014 ( $P$. persica). 'MP-29' is reproductively sterile and is useful only as a rootstock.

\section{Description} erate vigor and a semispreading form. Leaves are red with a morphology intermediate be-

Received for publication 31 Aug. 2011. Accepted for publication 28 Nov. 2011.

${ }^{2}$ Associate Professor.

${ }^{3}$ Professor Emeritus.

${ }^{4}$ To whom reprint requests should be addressed; e-mail Tom.Beckman@ars.usda.gov.
Unbudded trees of 'MP-29' display mod-

${ }^{1}$ Research Horticulturist. tween the plum and peach parents. Flowers are rare with multiple pistils but lacking sepals, petals, and anthers. No fruit have ever been observed on trees of 'MP-29'. At the Byron location, vegetative budbreak typically coincides with peach cultivars requiring $\approx 750 \mathrm{~h}$ of chilling below $7{ }^{\circ} \mathrm{C}\left(45^{\circ} \mathrm{F}\right)$ to break the rest period. 'MP-29' is readily propagated using softwood or hardwood cuttings or through tissue culture.
'Redhaven' peach trees budded on 'MP29' and planted in a field trial at the Byron location on an ARR- and PTSL-infested site displayed significantly better resistance to ARR than did those budded on 'Guardian' or 'Sharpe' (Table 1). Methodology for distinguishing tree mortality resulting from PTSL or ARR has previously been described (Beckman et al., 1998). Susceptibility to ARR is a significant weakness of 'Guardian' rootstock (Beckman et al., 1997, 1998). The ARR resistance of 'MP-29' was also better than that of 'Sharpe', which was released in 2007 to address this deficiency of 'Guardian' (Beckman et al., 2008). Southeastern peach growers will generally push up blocks once tree mortality climbs to $50 \%$ (Beckman, personal observation). Based on this criterion, had this block been planted on 'Guardian', it would have certainly been removed after only eight growing seasons (Table 2) and likely even earlier given establishment losses and other causes during the course of this trial. Although this trial was on a severe PTSL site (based on previous plantings), losses to this cause were minimal during the course of the trial. Unfortunately, a susceptible control had not been included and, as it turned out, all of the other treatments
Table 1. Rootstock influence on cumulative mortality resulting from Armillaria root rot (ARR), peach tree short life (PTSL), and other causes on a severe ARR and PTSL site ${ }^{z}$ (Byron, 2000-2010).

\begin{tabular}{lccccc}
\hline Rootstock & No. & Percent alive & Percent ARR & Percent PTSL & Percent other \\
\hline MP-29y & 50 & $60 \mathrm{a}^{\mathrm{x}}$ & $12 \mathrm{c}$ & $2 \mathrm{~b}$ & $26 \mathrm{a}$ \\
Sharpe $^{\mathrm{y}}$ & 50 & $40 \mathrm{a}$ & $36 \mathrm{~b}$ & $14 \mathrm{a}$ & $10 \mathrm{a}$ \\
Guardian $^{\mathrm{w}}$ & 50 & $12 \mathrm{~b}$ & $72 \mathrm{a}$ & $6 \mathrm{ab}$ & $10 \mathrm{a}$ \\
\hline
\end{tabular}

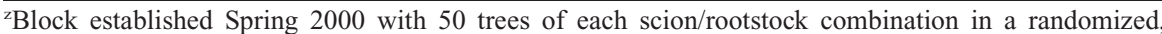
complete block design with 10 replications of five tree plots each. Trees were budded with 'Redhaven' peach and planted at a spacing of $0.6 \mathrm{~m}$ between trees within plot, $1.2 \mathrm{~m}$ between plots, and $6.1 \mathrm{~m}$ between rows. Trees were summer-pruned with a hedger; otherwise, they were managed according to commercial recommendations. No supplemental irrigation was applied.

y'MP-29' (plum $\times$ peach interspecific hybrid) and 'Sharpe' (plum hybrid) rootstocks propagated through softwood cuttings.

${ }^{\mathrm{x}}$ Mean separation within columns by Waller-Duncan test, $\mathrm{k}$-ratio $=100$. Cumulative percent mortality data were transformed as arcsine (square root) before analysis (Gomez and Gomez, 1984); untransformed means presented. Data analyzed by General Linear Models (GLM) program of the Statistical Analysis System for personal computers (SAS Institute, Inc., 2003).

w'Guardian’ selection SL2891 (component of bulk commercial lot).

Table 2. Rootstock influence on the time course of tree mortality (\%) resulting from Armillaria root rot (ARR) of 'Redhaven' peach trees planted on a severe ARR and PTSL site ${ }^{z}$ (Byron, 2000-2010).

\begin{tabular}{lccrrrrrrr}
\hline & \multicolumn{1}{c}{ Yr } \\
\cline { 2 - 9 } Rootstock & 2002 & 2003 & 2004 & 2005 & 2006 & 2007 & 2008 & 2009 & 2010 \\
\hline MP-29 $^{y}$ & 0 & 2 & $2 \mathrm{~b}^{\mathrm{x}}$ & $8 \mathrm{~b}$ & $8 \mathrm{~b}$ & $8 \mathrm{c}$ & $8 \mathrm{c}$ & $8 \mathrm{c}$ & $12 \mathrm{c}$ \\
Sharpe $^{\mathrm{y}}$ & 0 & 6 & $8 \mathrm{ab}$ & $12 \mathrm{~b}$ & $16 \mathrm{~b}$ & $22 \mathrm{~b}$ & $22 \mathrm{~b}$ & $26 \mathrm{~b}$ & $36 \mathrm{~b}$ \\
Guardian $^{\mathrm{w}}$ & 4 & 18 & $32 \mathrm{a}$ & $44 \mathrm{a}$ & $46 \mathrm{a}$ & $54 \mathrm{a}$ & $56 \mathrm{a}$ & $68 \mathrm{a}$ & $72 \mathrm{a}$ \\
\hline
\end{tabular}

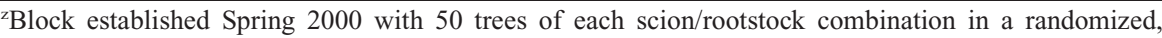
complete block design with 10 replications of five tree plots each. Trees were budded with 'Redhaven' peach and planted at a spacing of $0.6 \mathrm{~m}$ between trees within plot, $1.2 \mathrm{~m}$ between plots, and $6.1 \mathrm{~m}$ between rows. Trees were summer-pruned with a hedger; otherwise, they were managed according to commercial recommendations. No supplemental irrigation was applied.

y'MP-29' (plum $\times$ peach interspecific hybrid) and 'Sharpe' (plum hybrid) rootstocks propagated through softwood cuttings.

${ }^{\mathrm{x}}$ Mean separation within columns by Waller-Duncan test, k-ratio $=100$. Percent mortality data were transformed as arcsine (square root) before analysis (Gomez and Gomez, 1984); untransformed means presented. Data analyzed by General Linear Models (GLM) program of the Statistical Analysis System for personal computers (SAS Institute, Inc., 2003).

w'Guardian' selection SL2891 (component of bulk commercial lot). 
Table 3. Rootstock influence on cumulative mortality resulting from Armillaria root rot (ARR), peach tree short life (PTSL), and other causes on a severe Armillaria infested/inoculated site in central Georgia ${ }^{z}$ (Byron, 2005-2010).

\begin{tabular}{|c|c|c|c|c|c|}
\hline Rootstock & No. & Percent alive & Percent ARR & Percent PTSL & Percent other \\
\hline$\overline{\mathrm{MP}-29^{\mathrm{y}}}$ & 50 & $88 \mathrm{a}^{\mathrm{x}}$ & $8 \mathrm{~b}$ & $0 \mathrm{a}$ & $4 \mathrm{a}$ \\
\hline Sharpe ${ }^{y}$ & 50 & $60 \mathrm{~b}$ & $14 \mathrm{~b}$ & $4 \mathrm{a}$ & $22 \mathrm{a}$ \\
\hline SL1923w & 50 & $48 \mathrm{~b}$ & $38 \mathrm{a}$ & $2 a$ & $12 \mathrm{a}$ \\
\hline
\end{tabular}

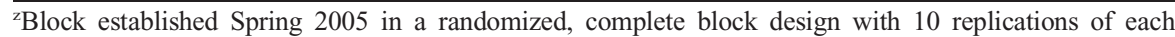
rootstock treatment (five trees per plot). Rootstocks were unbudded and planted at a spacing of $0.6 \mathrm{~m}$ between trees within plots, $1.2 \mathrm{~m}$ between plots, and $6.1 \mathrm{~m}$ between rows. Trees were provided supplemental inoculum with a single Armillaria infested acorn (same isolate as found naturally on trial site) as previously described (Beckman and Pusey, 2001). Trees were summer-pruned with a hedger; otherwise, they were managed according to commercial recommendations. No supplemental irrigation was applied.

y'MP-29' (plum $\times$ peach interspecific hybrid) and 'Sharpe' (plum hybrid) rootstocks propagated through softwood cuttings.

${ }^{\mathrm{x}}$ Mean separation within columns by Waller-Duncan test, k-ratio $=100$. Percent mortality data were transformed as arcsine (square root) before analysis (Gomez and Gomez, 1984); untransformed means presented. Data analyzed by General Linear Models (GLM) program of the Statistical Analysis System for personal computers (SAS Institute, Inc., 2003)

wSL1923 is an open-pollinated peach seedling rootstock selection out of BY520-8, which is a sibling of BY520-9, the progenitor of 'Guardian' peach rootstock (Okie et al., 1994).

Table 4. Rootstock influence on cumulative mortality resulting from Armillaria root rot (ARR), peach tree short life (PTSL), and other causes on a severe Armillaria infested grower site in central Georgia ${ }^{\mathrm{z}}$ (Fort Valley, 2007-2011).

\begin{tabular}{lccccr}
\hline Rootstock & No. & Percent alive & Percent ARR & Percent PTSL & Percent other \\
\hline MP-29 $^{\mathrm{y}}$ & 50 & $92 \mathrm{a}^{\mathrm{x}}$ & $0 \mathrm{c}$ & $0 \mathrm{~b}$ & $8 \mathrm{a}$ \\
Sharpe $^{\mathrm{y}}$ & 40 & $40 \mathrm{~b}$ & $18 \mathrm{~b}$ & $30 \mathrm{a}$ & $13 \mathrm{a}$ \\
Guardian $^{\mathrm{w}}$ & 50 & $42 \mathrm{~b}$ & $48 \mathrm{a}$ & $0 \mathrm{~b}$ & $10 \mathrm{a}$ \\
\hline
\end{tabular}

zBlock established Spring 2007 in a randomized, complete block design with eight or 10 replications of each rootstock treatment (five trees per plot). Trees were budded with 'Majestic' peach and planted at a spacing of $4.9 \mathrm{~m}$ between trees within row and $6.1 \mathrm{~m}$ between rows. Trees and rows were aligned so as to match tree locations of previous planting. Trees were managed according to commercial recommendations. No supplemental irrigation was applied.

y'MP-29' (plum $\times$ peach interspecific hybrid) and 'Sharpe' (plum hybrid) rootstocks propagated through softwood cuttings.

${ }^{\mathrm{x}}$ Mean separation within columns by Waller-Duncan test, k-ratio $=100$. Percent mortality data were transformed as arcsine (square root) before analysis (Gomez and Gomez, 1984); untransformed means presented. Data analyzed by General Linear Models (GLM) program of the Statistical Analysis System for personal computers (SAS Institute, Inc., 2003).

w'Guardian' peach seedling rootstock was collected from a single seed line, SC3-17-7, now the dominant component of the bulk seed mix sold commercially.

Table 5. Rootstock influence on cumulative mortality resulting from peach tree short life (PTSL), Armillaria root rot (ARR), and other causes on a severe PTSL infested site in central Georgia ${ }^{z}$ (Byron, 2005-2011).

\begin{tabular}{lccccr}
\hline Rootstock & No. & Percent alive & Percent PTSL & Percent ARR & Percent other \\
\hline Guardian $^{\mathrm{y}}$ & 30 & $93 \mathrm{a}^{\mathrm{x}}$ & $0 \mathrm{~b}$ & $3 \mathrm{a}$ & $3 \mathrm{~b}$ \\
MP-29 $^{\mathrm{w}}$ & 50 & $78 \mathrm{~b}$ & $6 \mathrm{ab}$ & $0 \mathrm{a}$ & $16 \mathrm{~b}$ \\
R97605.1 & 25 & $16 \mathrm{c}$ & $24 \mathrm{a}$ & $0 \mathrm{a}$ & $60 \mathrm{a}$ \\
\hline
\end{tabular}

${ }^{\mathrm{z} B}$ lock established Spring 2005 with up to 50 trees of each scion/rootstock combination in a randomized, complete block design with up to 10 replications of five tree plots each.

y'Guardian' peach seedling rootstock was collected from a single seed line, SC3-17-7, now the dominant component of the bulk seed mix sold commercially.

${ }^{\mathrm{x}}$ Mean separation within columns by Waller-Duncan test, $\mathrm{k}$-ratio $=50$. Cumulative percent mortality data were transformed as arcsine (square root) before analysis (Gomez and Gomez, 1984); untransformed means presented. Data analyzed by General Linear Models (GLM) program of the Statistical Analysis System for personal computers (SAS Institute, Inc., 2003).

wPropagated by hardwood cuttings.

${ }^{\mathrm{v}} \mathrm{R} 97605.1$ is an open-pollinated peach seedling rootstock selection out of a feral peach population found in Florida.

included in this trial evidently possessed good resistance to PTSL (data not shown).

Unbudded trees of 'MP-29' suffered numerically lower losses to ARR than did trees of 'Sharpe' and significantly lower losses than did trees of the peach seedling rootstock selection SL1923 in an ongoing Armillaria inoculation trial at the Byron location (Table 3 ).

'Majestic' peach trees budded onto 'MP29' and planted on a severe Armillaria-infested to those budded on 'Guardian' peach seedling rootstock (Table 5), the current industry standard (Beckman and Lang, 2003; Okie et al., 1994), in an ongoing field trial at the Byron location on a site with a known history of PTSL. In contrast, tree losses to PTSL on R97605.1, a peach seedling rootstock selection included in this trial, were significant.

'MP-29' displayed no visible galling in a field trial at the Byron location on a site infested with the Southern root-knot nematode (Meloidogyne incognita). The performance of 'MP-29' was comparable to 'Nemaguard' seedlings, which are regarded as resistant to this nematode (Sharpe, 1974). 'Lovell' seedlings, regarded as susceptible to $M$. incognita (Sharpe, 1974), were severely galled in the same trial. 'MP-29' also displayed no visible galling in a field trial in northern Florida on a site infested with $M$. floridensis. The performance of 'MP-29' was comparable to Flordaguard seedlings, which are regarded as resistant to this nematode (Sherman, et al., 1991). 'Nemaguard' seedlings, regarded as susceptible to M. floridensis (Sherman et al., 1991), were severely galled in the same trial.

'Redhaven' peach trees budded on 'MP29' displayed significantly lower vigor than those budded on 'Guardian' and similar to that of trees budded on 'Sharpe' (Table 6) in a field trial at the Byron location. The trunk cross-sectional area of trees budded on 'MP29 ' was $\approx 75 \%$ of those budded on 'Guardian' rootstock (similar to those budded on 'Sharpe', $\approx 60 \%$ of 'Guardian') after 11 growing seasons. Hence, 'MP-29' may prove useful as a semidwarf (or tree size-reducing) rootstock for peach.

Young 'Redhaven' trees budded on 'MP29' displayed similar or lower annual yields on a per-tree basis than did those budded on 'Guardian' (Table 7). This is probably the result of the lower vigor of peach varieties on 'MP-29' rootstock. However, once trees on 'MP-29' filled their allotted growing space in this trial $(\approx 4-5$ years; Beckman, personal observation), their yield typically exceeded those on 'Guardian' rootstock, although these differences were not always significant.

Yield efficiency (yield per unit trunk crosssectional area) of mature 'Redhaven' peach trees budded on 'MP-29' was significantly better than those budded on 'Guardian' or 'Sharpe' (Table 8). This suggests that if trees on 'MP-29' were planted at a higher density to compensate for their lower vigor, then per-hectare yields at maturity should equal or possibly exceed those budded on 'Guardian'.

'Redhaven' peach trees budded on 'MP29' generally displayed similar average fruit weight as those budded on 'Guardian'. Average fruit weight of 'Redhaven' trees on both 'MP29' and 'Guardian' was significantly higher than those budded on 'Sharpe' (Table 9). Reduced yield and fruit weight has been a deficiency for peach trees budded on 'Sharpe' rootstock, which will likely limit its use despite its generally good disease resistance.

Trees budded on 'MP-29' and 'Sharpe' produced fewer root suckers than did trees budded on 'Guardian'; although differences were 
Table 6. Rootstock influence on trunk cross-sectional $\operatorname{area}^{\mathrm{z}}\left(\mathrm{cm}^{2}\right)$ of 'Redhaven' peach trees planted on a site in central Georgia ${ }^{y}$ (Byron, 2000-2010).

\begin{tabular}{lcccrrrrrrc}
\hline & \multicolumn{10}{c}{ Yr } \\
\cline { 2 - 10 } Rootstock $^{n}$ & 2001 & 2002 & 2003 & \multicolumn{1}{c}{2004} & \multicolumn{1}{c}{2005} & 2006 & 2007 & 2008 & 2009 & 2010 \\
\hline Guardian $^{\mathrm{x}}$ & $26.6 \mathrm{a}^{\mathrm{w}}$ & $45.2 \mathrm{a}$ & $87.9 \mathrm{a}$ & $113.1 \mathrm{a}$ & $136.2 \mathrm{a}$ & $158.7 \mathrm{a}$ & $175.5 \mathrm{a}$ & $190.0 \mathrm{a}$ & $204.4 \mathrm{a}$ & $218.3 \mathrm{a}$ \\
MP-29v $^{\mathrm{v}}$ & $17.1 \mathrm{~b}$ & $31.9 \mathrm{~b}$ & $57.0 \mathrm{~b}$ & $66.2 \mathrm{~b}$ & $88.0 \mathrm{~b}$ & $99.7 \mathrm{~b}$ & $112.3 \mathrm{~b}$ & $125.2 \mathrm{~b}$ & $145.7 \mathrm{~b}$ & $162.3 \mathrm{~b}$ \\
Sharpe $^{\mathrm{v}}$ & $15.8 \mathrm{~b}$ & $33.3 \mathrm{~b}$ & $51.6 \mathrm{~b}$ & $64.8 \mathrm{~b}$ & $83.0 \mathrm{~b}$ & $98.6 \mathrm{~b}$ & $118.9 \mathrm{~b}$ & $127.8 \mathrm{~b}$ & $138.7 \mathrm{~b}$ & $149.7 \mathrm{~b}$ \\
\hline
\end{tabular}

${ }^{\mathrm{z} E s t i m a t e d ~ f r o m ~ t r u n k ~ d i a m e t e r ~ m e a s u r e d ~} 30 \mathrm{~cm}$ above soil line.

${ }^{\text {yB }}$ lock established Spring 2000 in a randomized, complete block design with eight single-tree replications of each rootstock treatment. Trees planted at a spacing of $1.8 \mathrm{~m}$ between trees within row and $6.1 \mathrm{~m}$ between rows. Trees were trained to a two-arm open-center design and otherwise managed according to commercial recommendations. Supplemental irrigation was applied through a drip system during periods of prolonged drought.

“'Guardian' peach seedling rootstock selection SL2891 (component of bulk commercial seedlot).

${ }^{w}$ Mean separation within columns by Waller-Duncan test, k-ratio $=100$. Data analyzed by General Linear Models (GLM) program of the Statistical Analysis System for personal computers (SAS Institute, Inc., 2003). vPropagated by hardwood cuttings.

Table 7. Rootstock influence on annual and cumulative yield ( $\mathrm{kg} / \mathrm{tree})$ of 'Redhaven' peach trees planted on a site in central Georgia ${ }^{z}$ (Byron, 2000-2010).

\begin{tabular}{lrrrrrrrrrr}
\hline & \multicolumn{10}{c}{ Yr } \\
\cline { 2 - 10 } Rootstock & 2002 & 2003 & 2004 & 2005 & 2006 & 2007 & 2008 & 2009 & 2010 & Cumulative \\
\hline MP-29 $^{\mathrm{y}}$ & $2.5 \mathrm{~b}^{\mathrm{x}}$ & $18.4 \mathrm{~b}$ & $12.8 \mathrm{a}$ & $13.7 \mathrm{a}$ & $15.3 \mathrm{a}$ & No data $^{\mathrm{w}}$ & $14.9 \mathrm{a}$ & $7.5 \mathrm{a}$ & $24.5 \mathrm{a}$ & $109.6 \mathrm{a}$ \\
Guardian $^{\mathrm{v}}$ & $5.6 \mathrm{a}$ & $26.9 \mathrm{a}$ & $13.0 \mathrm{a}$ & $13.4 \mathrm{a}$ & $8.6 \mathrm{~b}$ & No data & $9.5 \mathrm{a}$ & $3.0 \mathrm{~b}$ & $18.3 \mathrm{a}$ & $99.4 \mathrm{a}$ \\
Sharpe $^{\mathrm{y}}$ & $1.9 \mathrm{~b}$ & $11.6 \mathrm{c}$ & $8.2 \mathrm{~b}$ & $4.4 \mathrm{~b}$ & $3.4 \mathrm{c}$ & No data & $0.4 \mathrm{c}$ & $0.1 \mathrm{c}$ & $8.0 \mathrm{~b}$ & $36.4 \mathrm{~b}$ \\
\hline
\end{tabular}

${ }^{z}$ Block established Spring 2000 in a randomized, complete block design with eight single-tree replications of each rootstock treatment. Trees planted at a spacing of $1.8 \mathrm{~m}$ between trees within row and $6.1 \mathrm{~m}$ between rows. Trees were trained to a two-arm open center design and otherwise managed according to commercial recommendations. Supplemental irrigation was applied by a drip system during periods of prolonged drought.

y Propagated by hardwood cuttings.

${ }^{x}$ Mean separation within columns by Waller-Duncan test, k-ratio $=100$. Data analyzed by General Linear Models (GLM) program of the Statistical Analysis System for personal computers (SAS Institute, Inc., 2003).

wSevere late freeze in 2007 eliminated crop. Late frosts in 2008 and 2009 reduced crop.

"Guardian' peach seedling rootstock selection SL2891 (component of bulk commercial seedlot).

Table 8. Rootstock influence on annual and cumulative yield efficiency $\left(\mathrm{kg} \cdot \mathrm{cm}^{-2}\right)$ of 'Redhaven' peach trees planted on a site in central Georgia ${ }^{z}$ (Byron, 2000-2010).

\begin{tabular}{lcccccccccc}
\hline & \multicolumn{10}{c}{ Yr } \\
\cline { 2 - 10 } Rootstock & 2002 & 2003 & 2004 & 2005 & 2006 & 2007 & 2008 & 2009 & 2010 & Cum \\
\hline MP-29 $^{\mathrm{y}}$ & $0.07 \mathrm{~b}^{\mathrm{x}}$ & $0.33 \mathrm{a}$ & $0.19 \mathrm{a}$ & $0.16 \mathrm{a}$ & $0.16 \mathrm{a}$ & no data & $0.12 \mathrm{a}$ & $0.05 \mathrm{a}$ & $0.15 \mathrm{a}$ & $0.68 \mathrm{a}$ \\
Guardian $^{\mathrm{v}}$ & $0.12 \mathrm{a}$ & $0.33 \mathrm{a}$ & $0.13 \mathrm{~b}$ & $0.10 \mathrm{~b}$ & $0.06 \mathrm{~b}$ & no data & $0.05 \mathrm{~b}$ & $0.01 \mathrm{~b}$ & $0.09 \mathrm{~b}$ & $0.48 \mathrm{~b}$ \\
Sharpe $^{\mathrm{y}}$ & $0.06 \mathrm{~b}$ & $0.23 \mathrm{a}$ & $0.13 \mathrm{ab}$ & $0.05 \mathrm{c}$ & $0.04 \mathrm{~b}$ & no data & $0.00 \mathrm{c}$ & $0.00 \mathrm{~b}$ & $0.05 \mathrm{~b}$ & $0.23 \mathrm{c}$
\end{tabular}

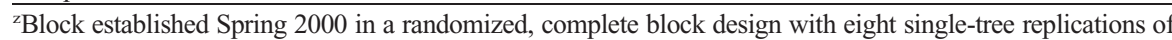
each rootstock treatment. Trees planted at a spacing of $1.8 \mathrm{~m}$ between trees within row and $6.1 \mathrm{~m}$ between rows Trees were trained to a two-arm open center design and otherwise managed according to commercial recommendations. Supplemental irrigation was applied by a drip system during periods of prolonged drought. yPropagated by hardwood cuttings.

${ }^{\mathrm{x}}$ Mean separation within columns by Waller-Duncan test, k-ratio $=100$. Data analyzed by General Linear Models (GLM) program of the Statistical Analysis System for personal computers (SAS Institute, Inc., 2003). wSevere late freeze in 2007 eliminated crop. Late frosts in 2008 and 2009 significantly reduced crop.

v'Guardian' peach seedling rootstock selection SL2891 (component of bulk commercial seedlot).

Table 9. Rootstock influence on fruit weight (g/fruit) of 'Redhaven' peach trees planted on a site in centra Georgia $^{z}$ (Byron, 2000-2010).

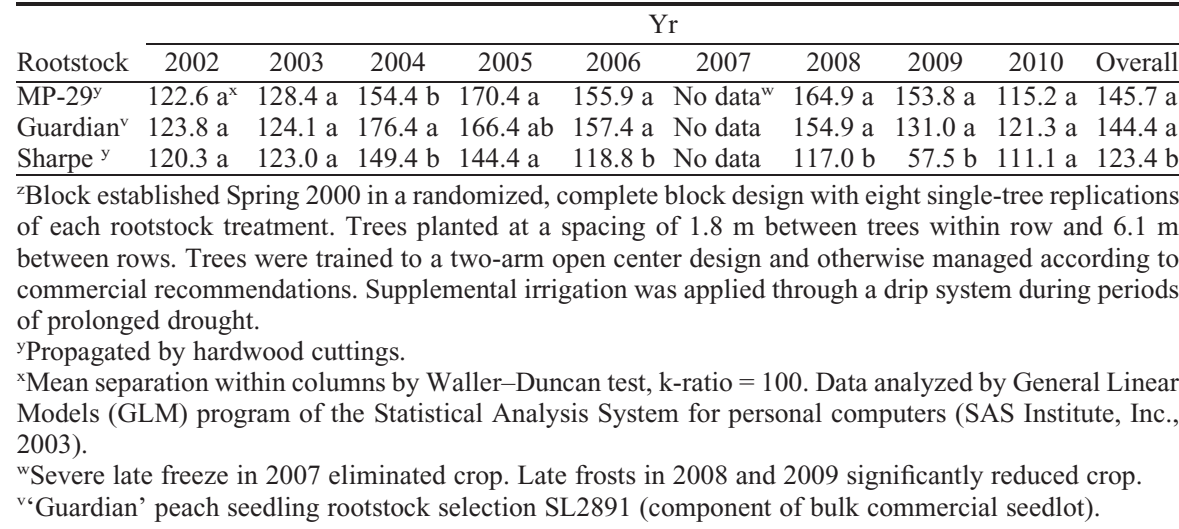

generally not statistically significant (Table 10), all three rootstocks averaging approximately one sucker per year. However, this is based on sucker counts in the fall, which typically only account for those present at the base of trees. Both 'MP-29' and 'Sharpe' start to produce rootstock suckers out away from the trunk after $\approx 5-7$ years (Beckman, personal observation). These are difficult to account for because they are routinely mowed down mechanically or burned down with post-emergence herbicides during the growing season. Nevertheless, they may pose a risk should growers attempt to chemically mow the orchard floor with a systemic nonselective post-emergent herbicide such as glyphosphate.

'MP-29' has been tested for compatibility with a range of peach scions, including 'Delta', 'Faye Elberta', 'Fireprince', 'Flordaguard', 'Cresthaven', 'Harvester', 'Majestic', 'Redglobe', and 'Redhaven', all of which displayed satisfactory compatibility (observation periods range from 3 to 12 years and most are still in progress). Graft unions with peach scions are typically smooth. Tests of graft compatibility of 'MP-29' with other Prunus species have been initiated.

Overall, 'MP-29' appears to offer a unique combination of broad disease resistance, productivity, and vigor control not found in any other currently available rootstock for peach in the United States. These attributes suggest it for trial in the main peach production areas of the southeast United States and in other production areas suffering similar disease issues.

\section{Availability}

A plant patent application has been filed for 'MP-29'. The Florida Foundation Seed Producers, Inc., Gainesville, FL, will be the licensing agent for 'MP-29'. Neither the USDA-ARS nor the University of Florida have trees of 'MP-29' for distribution. Budwood of 'MP-29' has been deposited in the IR-2 Fruit Tree Collection where it is available for research purposes, including development and commercialization of new varieties or rootstocks. Virus-indexed budwood is available from National Virus-Tested Fruit Tree Program, WSU-IAREC, 24106 N. Bunn Road, Prosser, WA 99350-9687.

\section{Literature Cited}

Beckman, T.G., J.X. Chaparro, and W.B. Sherman. 2008. 'Sharpe', a clonal plum rootstock for peach. HortScience 43:2236-2237.

Beckman, T.G. and G.A. Lang. 2003. Rootstock breeding for stone fruits. Acta Hort. 622:531551.

Beckman, T.G., W.R. Okie, A.P. Nyczepir, P.L. Pusey, and C.C. Reilly. 1998. Relative susceptibility of peach and plum germplasm to Armillaria root rot. HortScience 33:10621065.

Beckman, T.G., W.R. Okie, A.P. Nyczepir, G.L. Reighard, E.I. Zehr, and W.C. Newall. 1997. History, current status and future potential of 'Guardian'TM (BY520-9) peach rootstock. Acta Hort. 451:251-258. 
Table 10. Rootstock influence on root suckering (number/tree) of 'Redhaven' peach trees planted on a site in central Georgia ${ }^{z}$ (Byron, 2000-2010).

\begin{tabular}{lllllllllll}
\hline & \multicolumn{10}{c}{ Yr } \\
\cline { 2 - 11 } Rootstock $^{n}$ & 2002 & 2003 & 2004 & 2005 & 2006 & 2007 & 2008 & 2009 & 2010 & Cumulative \\
Guardian $^{\mathrm{y}}$ & $1.9 \mathrm{a}^{\mathrm{x}}$ & $3.5 \mathrm{a}$ & $0.5 \mathrm{a}$ & $1.0 \mathrm{a}$ & $1.9 \mathrm{a}$ & $1.6 \mathrm{a}$ & $1.0 \mathrm{a}$ & $0.4 \mathrm{~b}$ & $0.0 \mathrm{~b}$ & $11.8 \mathrm{a}$ \\
MP-29 $^{\mathrm{w}}$ & $0.5 \mathrm{ab}$ & $0.8 \mathrm{a}$ & $0.4 \mathrm{a}$ & $0.1 \mathrm{a}$ & $0.1 \mathrm{a}$ & $1.4 \mathrm{a}$ & $1.0 \mathrm{a}$ & $2.9 \mathrm{a}$ & $1.3 \mathrm{a}$ & $8.4 \mathrm{a}$ \\
Sharpe $^{\mathrm{w}}$ & $0.0 \mathrm{~b}$ & $1.3 \mathrm{a}$ & $1.4 \mathrm{a}$ & $1.6 \mathrm{a}$ & $2.4 \mathrm{a}$ & $1.5 \mathrm{a}$ & $0.4 \mathrm{a}$ & $0.3 \mathrm{~b}$ & $0.0 \mathrm{~b}$ & $8.7 \mathrm{a}$
\end{tabular}

${ }^{\mathrm{z}}$ Block established Spring 2000 in a randomized, complete block design with eight single-tree replications of each rootstock treatment. Trees planted at a spacing of $1.8 \mathrm{~m}$ between trees within row and $6.1 \mathrm{~m}$ between rows. Trees were trained to a two-arm open center design and otherwise managed according to commercial recommendations. Supplemental irrigation was applied through a drip system during periods of prolonged drought.

y‘Guardian' peach seedling rootstock selection SL2891 (component of bulk commercial seedlot).

${ }^{x}$ Mean separation within columns by Waller-Duncan test, $\mathrm{k}-\mathrm{ratio}=100$. Data analyzed by General Linear Models (GLM) program of the Statistical Analysis System for personal computers (SAS Institute, Inc., 2003).

wPropagated by hardwood cuttings. No suckers were observed on any trees in fall of 2001.
Beckman, T.G. and P.L. Pusey. 2001. Field testing peach rootstocks for resistance to Armillaria root rot. HortScience 36:101-103.

Gomez, K.A. and A.A. Gomez. 1984. Statistical procedures for agricultural research. Wiley, New York, NY.

Okie, W.R., T.G. Beckman, A.P. Nyczepir, G.L. Reighard, W.C. Newall, Jr., and E.I. Zehr. 1994. BY520-9, a peach rootstock for the southeastern United States that increases scion longevity. HortScience 29:705-706.

SAS Institute, Inc. 2003. SAS for Windows. Version 9.1. SAS Institute, Inc., Cary, NC.

Sharpe, R.H. 1974. Breeding peach rootstocks for the southern United States. HortScience 9:362-363.

Sherman, W.B., P.M. Lyrene, and R.H. Sharpe. 1991. Flordaguard peach rootstock. HortScience 26:427-428. 